\title{
Education of the New Generation Computer Science Students
}

\author{
By Estelle Taylor \\ Martin Park
}

In this paper the five major paradigms and their different theories and models are examined. A questionnaire was developed to determine the students' perceptions of aspects of the different paradigms. The results imply that none of the paradigms is more important than the others. Each theory is complemented by the other. Aspects of behaviourism that the students' felt was important were the atmosphere in the class and goal setting. Factors of the cognitivism paradigm that stood out were that students like to relate new knowledge to current knowledge and they remember things better when they know how things fit into the big picture. Factors of the constructivism paradigm that stood out were, once again, the atmosphere in the class and active involvement that enables students to learn better. There were a few factors of the design based paradigm that stood out, for example rewarding students for good behaviour, and the fact that some students prefer visual learning while others prefer verbal learning. The paper ends with recommendations that may be used to improve the teaching and learning of Computer Science students.

\section{Introduction}

The paper starts with a problem statement and the motivation for this study, followed by a literature study of the relevant paradigms, theories and methods. After this follows a description of the data collection, analysis and interpretation of the results. The paper ends with a conclusion.

\section{Problem Statement and Motivation}

Students have changed over the years and according to Oblinger \& Rickard (2003) today's students are part of a generation in transition. Prensky (2001) states that our students' brains have physically changed. Oblinger \& Rickard (2003) feels there is a gap widening between the teachers and students. As a result of this new generation students, there has to be a change in teaching and

${ }^{*}$ Senior Lecturer, North-West University, South Africa.

${ }^{\dagger}$ Student, North-West University, South Africa. 
learning methods. Furthermore, all subjects cannot have the same model of teaching. This problem is not adequately addressed even though there is proof that using different teaching and learning methods offers better value for a student.

To get possible answers on how to improve the methods used to teach a new generation of Computer Science students, the 5 major paradigms with the relevant theories and models were studied, and from the knowledge gained from this literature study, a questionnaire was developed to get feedback from the students on their preferences.

\section{Literature Study}

\section{Behaviourism}

Behaviourists' main focus is on studying stimulus events and how those events begin, end or change the behaviours. Behaviourism consists of a few theories and models namely the Classical Conditioning theory, the GOMS model, the Operant Conditioning and the Social Learning theory.

\section{Classical Conditioning Theory}

Classical conditioning is described by Cherry (2012) as a learning process that occurs through associations between an environmental stimulus and a natural occurring stimulus. Teachers should have a classroom with a positive atmosphere that helps students not to be scared or tense. Combining a fearful, tense student with these positive surroundings will teach him or her to make new associations.

\section{GOMS Model}

The model is a human information processing model that is used to anticipate what a user's behaviour will be in a situation. Hochstein (2002) states the behaviour of a person estimated in four different components. Firstly goals which can be described as what the person wants to achieve. Operators are the second component. As described by Hochstein (2002) it is "the elementary perceptual, motor or cognitive actions that are used to accomplish the goals". The third component is Methods. This is the steps that are followed to accomplish the goals that have been set in the beginning. The last component of the GOMS model is the Selection Rules. In this section the method that must be used to achieve the goal is stated. There can be many different methods to achieve the goal.

\section{Operant Conditioning}

Operant conditioning is the process of using positive or negative reinforcements to change the behaviour. The aim is that both these reinforcements increase the behaviour. On the other hand there is punishment which can also be positive or negative. Looking at the educational side examples of this operant conditioning is when a teacher gives points to the 
students who is the best behaved. The students will come to the conclusion that if they behave themselves they will earn extra points (Eberwein, 2012).

\section{Social Learning Theory}

The Social learning theory states that persons learn from one another. According to Sincero (2011) a person can learn by focussing on how other people perform the behaviour. Bandura (1977) developed a model process to see if the social learning is successful or not. The process consists of four steps. Step one is attention. The theory states that attention must be paid for learning to occur. Step two is retention. This is important for the newly learned behaviour, to retain the relevant data. Step three is reproduction. With reproduction you have to demonstrate the behaviour. The last step is motivation. If you are motivated to repeat the behaviour then you will keep on performing the behaviour and be successful.

\section{Cognitivism}

Cognitivism can be seen as the cognitive process that is part of learning. Guey, et al. (2010) states that this process consists of induction, deduction, finding rules and recognising patterns. The cognitive approach can be seen as a schemata development. This is according to Sims \& Lorenzi (1992) when the learner constructs a schema that is starts of simple and later gets more complex through experiences with certain instances. Understanding is the prime factor when the schema is constructed. The cognitive theories that will be looked at are Assimilation theory, Attribution theory, Cognitive Load theory, Cognitive Theory of Multimedia Learning and Elaboration theory.

\section{Assimilation Theory}

The idea behind this theory according to Whitehead \& Young (2008) is that a learner applies and incorporates new ideas into existing ideas already known by the learner. Meaningful learning can be seen when the new knowledge is related to already known knowledge in the cognitive structure of the learner. This means that more effort is required. Rote learning can be seen when the information is only memorized based on repetition. Goals can't be achieved learning this way.

Applying this theory in teaching the teacher needs to know what the students' prior knowledge is. From there the teaching process can start and the students can apply the new ideas and information given by the teacher to the existing information already known by the students.

\section{Attribution Theory}

Attribution theory looks at how people describe events and how it is related to how they think and act. When a person tries to understand why another person performed a certain action or said something may attribute causes to the certain behaviour. According to Culatta (2013) an attribution is underlined by a three stage process. The behaviour must be perceived or observed by a person, secondly the person must believe that the behaviour was 
purposely performed and then lastly the person must define whether they believe that the other person was forced to execute the behaviour.

Looking at the teaching part of this theory, important information is communicated to students by teachers through feedback on their assignments, grading their examinations and during class.

\section{Cognitive Load Theory}

When presenting information the Cognitive Load theory can provide guidance in a way that boosts learner activities that optimise creative activities. The theory is based on a cognitive architecture. Kirschner (2002) states that Cognitive Load theory assumes a restricted memory linked to an unrestricted long-term memory. The brain can only process a limited of new information, thus the brain has only a limited capacity to memorize a list of items. The problem then appears that students are overloaded by the teachers. Teachers must provide instruction in a manner that learning in working memory can be relocated to long term memory. Therefore attention must be given to how much information is given to a learner at a time.

\section{Cognitive Theory of Multimedia Learning}

"A picture is worth a thousand words" as mentioned by Mayer \& Valerie (1994). The multimedia principle states according to Mayer (2005) that learning is more effective when pictures and words occur rather than just words. This does not mean that when pictures and words are available that learning would definitely improve. The theory addresses how to use the pictures and words to improve learning.

\section{Elaboration Theory}

The theory deals firstly with the simple tasks and moves to the more complex tasks as the person progresses. When teaching the simplest version of the concept, principle or task must be taught first. Make sure that these simplest versions are understood before continuing with the more complex ones that elaborate on them. Applying this theory in the class can be done by teaching wider, more inclusive concepts before the more detailed concepts are taught that elaborate these inclusive concepts.

\section{Constructivism}

Constructivism is defined by the reference to four principles. Firstly if learning occurs in an important way it depends on knowledge that is already known. Secondly new ideas occur as we change our old ideas. Thirdly learning is associated with inventing ideas and not by accumulating facts. Lastly when we rethink old ideas and then new conclusions is reached for new ideas which conflict with our old ideas then meaningful learning occurs (Gray, 1997). Constructivist teaching is when students are involved in the process of meaning and knowledge construction and not only receiving information. It also demands critical thinking and develop students to be motivated and independent. The theories and approaches that will be looked at are Discovery 
Learning, Social Development Theory, Problem Based Learning and Situated Learning.

\section{Discovery Learning}

Discovery learning approaches are designed to engage students in inquiry through which, guided by the teacher and materials, they discover the intended content (Hammer, 1997). As one can see from the name of the theory, discovery learning implies that it is the best if the learner discovers facts and relationships for themselves. Students use their past experience and current knowledge to discover the facts and relationship of a problem they must solve.

\section{Social Development Theory}

Social Development can be described as a process where human energies and activities at higher levels are organised to achieve better results. Development improves the potential of a human. Within Social Development theory the students play an active role in learning. The roles of the teacher and students are shifted, as a teacher should collaborate with the students to help facilitate meaning construction in students.

\section{Problem based Learning}

Hmelo-Silver (2004) states that Problem Based Learning (PBL) can be seen as a student centered pedagogy where learning of a topic occurs through the experience of problem solving. By doing this they can learn both content and thinking strategies. Learning is most effective in small groups, usually between 6 and 10 people. Teachers are only there for guidance not for teaching. A problem forms the basis for the focus of the group and it stimulates learning. The problem is there to develop problem solving skills.

\section{Situated Learning}

The simplest definition of situated learning is that it is learning that occurs in the same context in which it is applied. Situated Learning Theory states that learning is unintentional and situated within authentic activity, culture and time. Lave \& Wegner (1991) mentions that we should not see learning as the transmission of abstract knowledge from one person to another. It should rather be seen as a social process where knowledge is reconstructed.

\section{Design-Based}

Design-based Research (DBR) experiments were developed to do formative research to test and improve educational designs grounded on principles developed from prior research. DBR has the intention to address numerous needs and problems central to the study of learning. The two DesignBased models that will be looked at are the ADDIE Model of Instructional Design and the ARCS Model of Motivational Design. 
ADDIE Model of Instructional Design

A process that is generally used by instructional designers and training developers is the ADDIE instructional design model. The model is at the core of instructional design and is the basis of instructional systems design. The ADDIE model consists of five steps namely analysis, design, development, implementation and evaluation (Davis, 2013).

\section{ARCS Model of Motivational Design}

The model was developed to promote and sustain motivation in the learning process. Poulsen et al. (2008) states that the model consists of the following steps namely attention, relevance, confidence and satisfaction.

\section{Humanism}

Humanisms main goal is the development of who are self-sufficient and self-actualized. A more personal and student-centered learning experience is used in humanism. The theories of Humanism that will be looked at are Experiential Learning, Emotional Intelligence and Maslow's Hierarchy of Needs.

\section{Experiential Learning}

Kolb (1984) states that learning is the process where knowledge is created through the transformation of experience. Most of this theory is concerned with the learner's internal cognitive process. New experiences help with the providence of the impetus for the development of new concepts (McLeod, 2010).

\section{Emotional Intelligence}

Emotional Intelligence is the ability to identify, use, understand and manage emotions in positive ways to get rid of stress, have effective communication, empathize with others, to overcome challenges and resolve conflict. The understanding of emotions can be used to relate people better to other people, achieve better success at work and to lead a more fulfilling life (Segal \& Smith, 2013). Goleman (1998) developed the mixed model that focuses on emotional intelligence as a wide array of competencies and skills to drive leadership performance. The model consists of five areas namely selfawareness, self-regulation, social skill, empathy and motivation. Emotional intelligence in education is not directly towards learning but rather to how the teacher handles the students.

Maslow's Hierachy of Needs

Maslow (1943) presented the idea that a person's actions are directed towards goal attainment. A number of functions could be satisfied by any given behaviour at the same time. Maslow's Hierarchy of Needs is represented in a hierarchical pyramid with five levels. The levels are:

- Self-actualization 
- Esteem

- Belongingness

- Safety

- Physiological

Self-actualization at the top level and can be considered as growth needs. The other four levels from bottom to top are considered as physiological needs. The higher-order needs can only influence behaviour if the lower-level needs are satisfied (Maslow, 1943).

\section{Data Collection and Analysis}

\section{Data Collection}

The questionnaire was emailed to 76 third year Computer Science and Information Technology students of the North-West University, Potchefstroom Campus, South Africa. The questionnaire was answered and returned by 49 students. The questionnaire covered aspects of all of the different theories and models that were investigated in the literature study of each of the different paradigms. Each question in the questionnaire can be linked with one or more of the characteristics of the different paradigms.

\section{Data Analysis}

Different statistical methods such as frequency count and probabilities were used to analyse the data. The open ended questions added some context to some of the multiple choice questions and were dealt with individually

\section{Results}

The multiple choice questions had five options:

1 (I strongly disagree)

2 (I disagree somewhat)

3 (I have no strong opinion) either way

4 (I agree somewhat)

5 (I strongly agree). 
Table 1. Shows the Results of the Multiple Choice Questions

\begin{tabular}{|c|c|c|c|c|c|}
\hline Questions & 1 & 2 & 3 & 4 & 5 \\
\hline $\begin{array}{l}\text { The atmosphere in the classroom has an influence on } \\
\text { teaching and learning }\end{array}$ & $0 \%$ & $0 \%$ & $0 \%$ & $33 \%$ & $67 \%$ \\
\hline $\begin{array}{l}\text { The atmosphere in the classroom has an influence on } \\
\text { student participation }\end{array}$ & $0 \%$ & $0 \%$ & $14 \%$ & $22 \%$ & $63 \%$ \\
\hline I learn by setting goals and sub goals & $0 \%$ & $12 \%$ & $18 \%$ & $49 \%$ & $20 \%$ \\
\hline Rewards for good work would encourage me to do better & $2 \%$ & $8 \%$ & $18 \%$ & $27 \%$ & $45 \%$ \\
\hline I prefer to do assignments in a group & $22 \%$ & $27 \%$ & $29 \%$ & $16 \%$ & $6 \%$ \\
\hline $\begin{array}{l}\text { It would help me to learn if students present some of the } \\
\text { topics in class }\end{array}$ & $20 \%$ & $20 \%$ & $47 \%$ & $12 \%$ & $0 \%$ \\
\hline When learning I memorize based on repetition & $6 \%$ & $14 \%$ & $22 \%$ & $33 \%$ & $24 \%$ \\
\hline $\begin{array}{l}\text { When learning it helps if I relate the new knowledge to } \\
\text { current knowledge }\end{array}$ & $0 \%$ & $0 \%$ & $8 \%$ & $49 \%$ & $43 \%$ \\
\hline I have to understand the work before I study & $4 \%$ & $8 \%$ & $18 \%$ & $33 \%$ & $37 \%$ \\
\hline I hav & $6 \%$ & $16 \%$ & $35 \%$ & $33 \%$ & $10 \%$ \\
\hline A lot & $0 \%$ & $4 \%$ & $16 \%$ & $43 \%$ & $37 \%$ \\
\hline I pref & $0 \%$ & $2 \%$ & $14 \%$ & $47 \%$ & $37 \%$ \\
\hline in an extra & $27 \%$ & $12 \%$ & $27 \%$ & $12 \%$ & $22 \%$ \\
\hline I und & $2 \%$ & $2 \%$ & $27 \%$ & $33 \%$ & $37 \%$ \\
\hline I pre & $4 \%$ & $8 \%$ & $41 \%$ & $31 \%$ & $16 \%$ \\
\hline I pr & $2 \%$ & $6 \%$ & $26 \%$ & $39 \%$ & $27 \%$ \\
\hline Video & $4 \%$ & $8 \%$ & $24 \%$ & $29 \%$ & $35 \%$ \\
\hline $\begin{array}{l}\text { I prefer } \\
\text { before }\end{array}$ & $0 \%$ & $6 \%$ & $24 \%$ & $39 \%$ & $31 \%$ \\
\hline $\begin{array}{l}\text { I remember things better when I know how th } \\
\text { big picture }\end{array}$ & $0 \%$ & $0 \%$ & $2 \%$ & $35 \%$ & $63 \%$ \\
\hline when I am interested in a topic & $0 \%$ & $0 \%$ & $4 \%$ & $12 \%$ & $84 \%$ \\
\hline I learn 1 & $0 \%$ & $6 \%$ & $16 \%$ & $39 \%$ & $39 \%$ \\
\hline $\begin{array}{l}\text { I learn more effect } \\
\text { lectures }\end{array}$ & $4 \%$ & $16 \%$ & $39 \%$ & $22 \%$ & $18 \%$ \\
\hline $\begin{array}{l}\text { Lecturers should guide learners in solving a problem } \\
\text { themselves instead of showing them how to solve the } \\
\text { problem }\end{array}$ & $2 \%$ & $12 \%$ & $31 \%$ & $39 \%$ & $16 \%$ \\
\hline I learn more effective in small groups than large groups & $2 \%$ & $0 \%$ & $2 \%$ & $41 \%$ & $45 \%$ \\
\hline $\begin{array}{l}\text { I learn from comparing my answers to the answe } \\
\text { others }\end{array}$ & $4 \%$ & 12 & $12 \%$ & $43 \%$ & $27 \%$ \\
\hline $\begin{array}{l}\text { I learn more when I am first given an problem and are } \\
\text { taught how to solve it }\end{array}$ & $2 \%$ & $12 \%$ & $18 \%$ & $37 \%$ & $31 \%$ \\
\hline 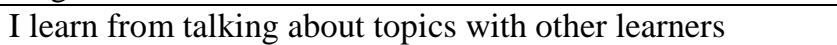 & $8 \%$ & $12 \%$ & $20 \%$ & $39 \%$ & $20 \%$ \\
\hline Disc & $2 \%$ & $2 \%$ & $8 \%$ & $49 \%$ & $39 \%$ \\
\hline cture & $4 \%$ & $8 \%$ & $24 \%$ & $37 \%$ & $27 \%$ \\
\hline Being a & $8 \%$ & $8 \%$ & $31 \%$ & $27 \%$ & $27 \%$ \\
\hline rience than from lectures & $2 \%$ & $4 \%$ & $22 \%$ & $29 \%$ & $43 \%$ \\
\hline I learn more from role-playing than from lectures & $14 \%$ & $24 \%$ & $29 \%$ & $27 \%$ & $6 \%$ \\
\hline I learn more when a variety of methods are used & $2 \%$ & $6 \%$ & $27 \%$ & $29 \%$ & $37 \%$ \\
\hline $\begin{array}{l}\text { I learn more when the work is related to industry and my } \\
\text { future profession }\end{array}$ & $0 \%$ & $2 \%$ & $8 \%$ & $31 \%$ & $59 \%$ \\
\hline $\begin{array}{l}\text { I find it easier to learn if I know exactly what is expected } \\
\text { of me }\end{array}$ & $0 \%$ & $2 \%$ & $4 \%$ & ${ }^{0}$ & $\%$ \\
\hline Learning a topic is easier when I have already written a & $6 \%$ & $12 \%$ & $27 \%$ & $20 \%$ & $35 \%$ \\
\hline
\end{tabular}




\begin{tabular}{|c|c|c|c|c|c|}
\hline $\begin{array}{l}\text { I prefer to listen to a lecturer explaining a topic rather than } \\
\text { seeing pictures about the topic }\end{array}$ & $12 \%$ & $20 \%$ & $35 \%$ & $24 \%$ & $8 \%$ \\
\hline $\begin{array}{l}\text { I find learning easier if the lecturer takes an interest in my } \\
\text { personal situation, background and needs }\end{array}$ & $8 \%$ & $22 \%$ & $31 \%$ & $22 \%$ & $16 \%$ \\
\hline
\end{tabular}

Students were asked to order a given list of factors according to their perception of its importance. Table 2 shows these results, from most important to least important.

Table 2. Factors in order of Importance

Positive atmosphere in classes and relationship with lecturer.

Interest in topic.

Exercises and hands-on experience, role-playing (Active participation in learning).

Use of multimedia.

Feedback from the lecturer.

Setting goals and sub goals.

The relationship between the work and industry or future profession.

Variety of methods used in teaching.

Class discussions.

Group work.

\section{Discussion of Results}

According to the results of the questionnaire behaviourism has a dramatic impact on the teaching and learning of students. One of the most influencing factors is the atmosphere in the classroom. As can be seen in table $167 \%$ of the students agreed that the atmosphere in the classroom has a big influence on teaching and learning. Another statistic states that $63 \%$ of the students agree strongly that the atmosphere in the classroom has an influence on how they participate.

Goal setting is an important factor to determine whether there is progress in completing the task. It is therefore not surprising that $69 \%$ of the students learn by setting goals and sub goals for themselves to see how they progress (49\% agrees somewhat and $20 \%$ agrees strongly). $72 \%$ of the students feel that being rewarded for good work will encourage them to do better.

It is seen in table 1 that $57 \%$ of the students still apply rote learning where they learn by memorizing things based on repetition. $80 \%$ of the students answered that they had to understand the work before they can actually study it. $70 \%$ of the students also felt that they understand the work better when they look at an overview of the work before each part is explained in detail. $98 \%$ of the students felt that they remember things better when they know how it would fit into the big picture.

It is quite clear from table 1 that specific feedback is preferred by the students above general feedback. Looking at table 2, feedback from the lecturer 
is listed as the $5^{\text {th }}$ most important factor for the students. $67 \%$ of the students prefer presentations that include images and video clips and only $8 \%$ would not prefer a presentation with images and videos.

From the open ended questions some interesting suggestions were that all students must have tablets or laptops to do work online in class. Digital textbooks will also then become handy. Students recommended that more practical examples must be shown in class, using technology. Students would also like access to videos of previous lectures.

The results imply that $78 \%$ of the students learn better when they are actively involved.

Another way for students to construct knowledge is to solve problems on their own and ask teachers for advice rather than getting the whole solution from the teacher. 55\% agreed on solving problems this way. $86 \%$ of the students prefer to work in small groups rather than large groups.

Reconstructing own knowledge can also occur when students compare their answers with each other and talk about the different questions. 70\% answered that they learn more effective by comparing answers. $88 \%$ answered that discovering new things on their own helps them to learn more.

$72 \%$ of the students answered that rewarding them for good work would definitely encourage them to do better. $72 \%$ refer hands-on experiences to attending a lecture. When a lecture consists of work that relates to the students' future profession they pay more attention to what is said. Some students prefer group work while others want to complete the work on their own.

\section{Conclusion}

Students have changed over the years and are part of a generation in transition. Teaching and learning methods for new generation students have different ideals and perceptions than 50 years ago.

The results imply that none of the paradigms is more important than the other. Each theory is complemented by the other. There are certain aspects of each paradigm that these students find more important than others.

In the classroom environment, the atmosphere in the class plays a critical role of the student's behaviour. A recommendation is that the lecturer makes sure that there is a positive atmosphere in the class.

Goal setting is one of the most important factors to complete a task. Thus, to study effectively the student must set goals and sub-goals when they are studying. Their behaviour will be influenced positively when they see that they are achieving the goals that they have set for themselves.

Factors of the cognitivism paradigm that stood out were that students like to relate new knowledge to current knowledge and they remember things better when they know how things fit into the big picture.

Feedback is one of the most important factors that help a student to learn from their previous work and mistakes. Therefore, specific feedback must be given to students on their assignments. 
Most students support the use of multimedia in the class. PowerPoint presentations, video clips and images are a few examples of how multimedia can be used in the classroom.

Constructivism occurs when the student himself constructs knowledge. Factors that stood out were the atmosphere in the class (a factor that also stood out in the behaviourism paradigm). Active involvement enables students to learn better. As seen from the questions on the cognitivism paradigm, it was once again found that images and video clips help students with learning. Most students prefer smaller groups or individual work when completing an assignment.

There were factors of the design-based paradigm that stood out. Rewarding students for good work is an encouraging factor, as also seen from the questions on behaviourism.

Every person is different, each having his own learning style. This is seen from the humanism paradigm, where some students prefer seeing the topic in pictures, while other students prefer listening to the lecturer explaining the topic.

Technology is part of every Computer Science student's life. A recommendation therefore is that technology must be applied to the elements of the different paradigms. Using technology in the classroom will automatically attract more attention from this type of student. The atmosphere of the class will then be more positive and the class will be presented in a more interesting way. Projectors can be used to show presentations, images and video clips. Video clips of class sessions can be made for the students to watch at home, when preparing for tests or revision of what occurred in class. Practical examples must be shown to the class. By using a tablet or laptop, the students can actively participate in the classroom.

\section{References}

Bandura, A. 1977. Social learning theory. http://www.jku.at/org/content/e54521/e54 528/e54529/e178059/Bandura_SocialLearningTheory_ger.pdf Date of access: 28 June 2013.

Cherry, K. 2012. Introduction to Classical Conditioning. http://psychology.about.com/ od/behavioralpsychology/a/classcond.html_Date of access: 20 Mar. 2013.

Culatta, R. 2013. Attribution Theory (B. Weiner). http://www.instructionaldesign. org/theories/attribution-theory.html Date of access: 1 Apr. 2013.

Davis, A.L. 2013. Using instructional design principles to develop effective information literacy instruction The ADDIE model. http://crln.acrl.org/content/ 74/4/205.full Date of access: 15 July 2013.

Eberwein, D. 2012. Learning Theory and Classroom Applications, http://www.exa miner.com/article/learning-theory-and-classroom- applications Date of access: 3 July 2013.

Goleman, D. 1998, Working with emotional intelligence. New York: Bantam Books.

Gray, A. 1997. Constructivist teaching and learning. SSTA Research Centre Report 97-07 
Guey, C, Chengand,Y \& Shibata,S. 2010 A Triarchal instruction model: integration of principles from Behaviorism, Cognitivism and Humanism. Procedia - Social and Behavioral Sciences, 9(1):105-118.

Hammer, D. 1997. Discovery learning and discovery teaching. Cognition and Instruction 15(4):485-529.

Hmelo-Silver, C.E. 2004. Problem-Based Learning: What and How Do Students Learn?. Educational Psychology Review 16(3):235-266.

Hochstein, L. 2002. GOMS. http://www.cs.umd.edu/class/fall2002/cmsc838s/tichi/ printer/goms.html Date of access: 31 April 2013.

Kirschner, P.A. 2002. Cognitive load theory: Implications of cognitive load theory on the design of learning. Learning and instruction 12(1):1-10.

Kolb, D.A. 1984, Experiential Learning: Experience as the Source of Learning and Development. Prentice-Hall, Inc., Englewood Cliffs, N.J

Lave, J. \& Wegner, E. 1991. Situated Learning. Legitimate peripheral participation, Cambridge: University of Cambridge Press.

Maslow, A.H. 1943, A Theory of Human Motivation. Psychological Review 50(4):370-396.

Mayer, R.E. \& Valerie K.S. (1994). For whom is a picture worth a thousand words?

Mayer, R.E. 2005. Cognitive theory of multimedia learning. The Cambridge handbook of multimedia learning: 31-48.

McLeod, S. 2010, Kolb - Learning Styles, http://www.simplypsychology.org/ learning-kolb.html Date of access: 20 July 2013.

Oblinger, D \& Rickard, W. 2003. The Next Generation student. Higher education leaders symposium

Poulsen, A., Lam, K., Cisneros,S. \& Trust,T. 2008. ARCS Model of Motivational Design

Pöyry, S. 1989. Technology is Part of Every Life. European Journal of Engineering Education, pp. 339-349.

Prensky, M. 2001. Digital Natives, Digital Immigrants. On The Horizon, vol. 9, no. 5 , October

Segal, S. \& Smith, M. 2013, Emotional Intelligence (EQ) Five Key Skills for Raising Emotional Intelligence, http://www.helpguide.org/mental/eq5_raising_emotional _intelligence.htm Date of access: 22 July 2013

Sims, H. P., Jr., \& Lorenzi, P. 1992. The new leadership paradigm: Social learning and cognition in organizations. Newbury Park, CA: Sage.

Sincero, S.M. 2011. Social Learning Theory. http://www.explorable.com/social-lear ning-theory Date of access: 30 April 2013.

Whitehead, J. \& Young, R. 2008. Ausubel's Assimilation Learning Theory: Theoretical Basis for Concept Maps and E-Maps. http://etec.ctlt.ubc.ca/510wiki /Ausubel's_Assimilation_Learning_Theory:_Theoretical_Basis_for_Concept_Ma ps_and_E-Maps Date of access: 26 May 2013.

Yuan, Y. \& McKelvey, B. 2004. Situated Learning Theory: Adding Rate and Complexity Effects via Kauffman's NK Model. Nonlinear Dynamics, Psychology, and Life Sciences 8(1):63-96. 